\title{
AKTIVITAS ANTIBAKTERI ISOLAT KAPANG ENDOFIT DARI KULIT NANAS (Ananas comosus $($ L. $)$ Meer)
}

\author{
Siti Hamidatul 'Aliyah ${ }^{1 *}$, Musfirotun ${ }^{1}$, Nur Antriana ${ }^{2}$ \\ ${ }^{1}$ Program Studi Farmasi, Sekolah Tinggi Ilmu Kesehatan Harapan Ibu Jambi \\ ${ }^{2}$ Program Studi Keperawatan, Sekolah Tinggi Ilmu Kesehatan Harapan Ibu Jambi \\ "Email korespondensi: sitihamidatula@ stikes-hi.ac.id
}

\begin{abstract}
Pineapple contains an enzyme called bromelain which is can be used as antiseptic of mouth, antibacterial, antifungal, and disinfectant. Endophytic mold is a microbe that forms colonies in healthy tissues of living organisms, generally, endophytic microbes do not cause harmful symptoms in the tissue of their host. This study aims to isolate the endophytic shell origin of pineapple peel that has acted as an antibacterial. A total of 3 endophytic capsules, Ac-I, Ac-II and Ac-III were isolated from pineapple skin using PDA media. The three isolates were purified and microscopic examinations were performed. Antibacterial testing was performed by fermentation to produce supernatant, then tested using disc method (Kirby-Bauer method) with Staphylococcus aureus and Escerichia coli test bacteria. The 3 isolates obtained only 1 isolate Ac-III isolates that have activity as antibacterial, with the inhibition zone diameter in bacterium Staphylococcus aureus 7.65 $\mathrm{mm}$ while in the bacterium Escerichia coli $6,9 \mathrm{~mm}$.
\end{abstract}

Keywords: antibacterial, endophytic mold, pineapple peel.

\section{PENDAHULUAN}

Infeksi merupakan proses masuknya mikroba patogen kedalam tubuh, kemudian berkembangbiak. Bakteri merupakan mikrorganisme yang dapat menyebabkan infeksi baik secara lokal maupun sistemik. Penyakit infeksi secara umum dapat diobati dengan obat antibakteri/antibiotik. Akan tetapi dengan semakin tingginya penggunaan antibiotik, dapat meningkatkan resistensi dari bakteri patogen. Resistensi terhadap antibiotik pada bakteri mendorong upaya penemuan obat baru yang lebih efektif dan aman. Selain itu penggunaan antibiotik kimiawi harganya relatif mahal dan menimbulkan beberapa efek samping bagi kesehatan, sehingga kapang endofit dapat menjadi salah satu alternatif untuk menghasilkan senyawa antibiotik untuk menghambat mikroba pantogen (Walpajri, Rodesia, \& Roza, 2014; Van Antwerpen, Rutherford, \& Vogel, 2002).

Kapang endofit merupakan mikroorganisme yang sebagian ataupun keseluruhan fase hidupnya ada pada tumbuhan inanganya tetapi tidak menimbulkan 
penyakit pada tumbuhan inang Fungi endofit biasanya ditemukan pada tumbuhan (Fitriarni \& Kasiamdari, 2018). Kapang endofit biasanya dapat diisolasi dari bagian tumbuhan baik daun, batang, bunga, buah dan biji (Roze, Chanda, \& Linz, 2011). Kapang endofit merupakan mikroorganisme yang menarik karena bersimbiosis dengan tumbuhan dan bermanfaat untuk pertahanan diri inangnya dari musuh alaminya (Faeth \& Fagan, 2002). Kapang endofit dapat meningkatkan pertahanan tanaman terhadap cekaman lingkungan baik abiotik aupun biotik. Beberapa kapang endofit menghasilkan zat toksik yang dapat melindungi tumbuhan inang dari pathogen misalnya tumbuhan lain, serangga, nematoda dan herbivora (Mousa \& Raizada, 2013).

Penelitian ini mengisolasi kapang endofit dari kulit nanas. Nanas merupakan salah satu tumbuhan yang banyak ditemukan di Jambi. Buah nanas mengandung enzim bromelin, vitamin, kalsium, fosfor, magnesium, zat besi, natrium, kalium, dekstrosa, dan sukrosa. Enzim bromelin pada nanas dapat digunakan sebagai antibakteri, anti jamur dan desinfektan (Rahmat, Ratih L., Nurhidayati, \& Ayu Bathini, 2015). Buah nanas yang muda dan yang matang sama-sama memiliki kandungan enzim bromelin, namun pada buah nanas yang muda lebih banyak mengandung enzim bromelin dari pada yang matang (Nurhidayah, Masriany, \& Masri, 2013).

Enzim bromelin dapat mengubah atau merusak struktur protein penyusun dinding luar sel bakteri sehingga berakibat dinding sel bakteri pecah (Eshamah, Han, Naas, Rieck, \& Dawson, 2013). Husniah \& Gunata, (2020), telah melaporkan bahwa ekstrak kulit nanas memiliki aktivitas antibakteri terutama pada bakteri gram positif. Selain itu, Fitriana et al (2016) juga telah melakukan penelusuran terhadap fungi endofit pada daun nanas yang berpotensi sebagai anti bakteri. Namun, informasi terkait isolasi kapang endofit pada kulit nanas yang berpotensi sebagai antibakteri masih sangat terbatas. Sehingga tujuan penelitian ini untuk mengisolasi kapang endofit dari kulit nanas yang memiliki aktivitas sebagai antibakteri. 


\section{METODE PENELITIAN}

\subsection{Pengambilan dan Penyiapan Sampel}

Kulit nanas diambil dari lahan perkebunan warga di Tangkit Baru, Kecamatan Sungai Gelam, Kabupaten Muaro Jambi, Provinsi Jambi. Sampel kulit nanas yang masih muda, berwarna hijau, dan segar dicuci bersih dengan air mengalir selama \pm 10 menit, kemudian diiris sepanjang $\pm 1 \mathrm{~cm}$ lalu dibilas dengan aquades steril, kemudian kulit nanas dikering anginkan diatas kertas saring steril kemudian permukaan kulit nanas disterilisasi dengan cara direndam dalam larutan alkohol $70 \%$ selama 1 menit, kemudian direndam dalam natrium hipoklorit $(\mathrm{NaOCl}) 1 \%$ selama 5 menit. Setelah itu dilakukan pengulangan direndam kembali dalam alkohol 70\% selama 1 menit. Selanjutnya, dibilas 3 kali dengan aquades steril

\subsection{Isolasi dan pemurnian Kapang Endofit}

Kulit nanas yang telah disterilisasi dan diiris sepanjang $1 \mathrm{~cm}$ diletakkan pada media Potato Dextrose Agar (PDA) yang telah dicampur dengan kloramfenikol 0,05mg/mL (Crozier, Thomas, Aime, Evans, \& Holmes, 2006). Setelah itu diinkubasi selama 5-7 hari pada suhu $37^{\circ} \mathrm{C}$, amati hingga ada pertumbuhan kapang, isolasi kapang endofit dilakukan dengan tiga kali pengulangan (triplo). Pada isolasi sampel yang pertama diberinama Ac-1 yang berarti Ananas comosus-1, begitu juga seterusnya pada sampel yang ke dua dan ketiga. Isolat kapang endofit yang tumbuh dan menunjukkan morfologi dan warna koloni yang berbeda kemudian dimurnikan untuk memperoleh isolat tunggal. Isolat yang telah murni kemudian dilakukan karakterisasi secara makroskopis dan mikroskopis (Noverita, Dinah Fitria, 2009).

\subsection{Pemeriksaan Makroskopis dan Mikroskopis}

Karakterisasi makroskopis kapang endofit dilakukan dengan mengamati morfologi koloni dan warna koloni. Morfologi koloni meliputi bentuk, tepian, dan elevasi dari koloni tersebut Sedangkan pemeriksaan mikroskopis dengan teknik pewarnaan sel vegetatif. Objek glass dan penutup dibersihkan dengan menggunakan alkohol 70\%, lalu teteskan sedikit larutan Lacto Fenol Cotton Blue (LFCB) ditengan permukaan objek glass, koloni kapang diambil dari bagian tepi 
media dan diletakkan di permukaan kaca objek. Selanjutnya hifa kapang diuraikan menggunakan jarum ose secara perlahan kemudian jika kapang sudah terurai ditutup dengan gelas penutup. Kemudian amati bentuk hifa dan warna hifa dibawah mikroskop dengan perbesaran mulai terkecil,

\subsection{Fermentasi Isolat Kapang Endofit}

Fermentasi kapang endofit dilakukan dengan cara fermentasi cair menggunakan media Potato Dextrose Borth (PDB). Koloni kapang endofit murni kemudian diambil menggunakan sedotan steril sebanyak 1 potongan dimasukkan kedalam medium PDB cair sebanyak $50 \mathrm{~mL}$ kemudian diinkubasi selama 5-7 hari pada suhu ruang dengan kultur diam (statis). Masing-masing kultur yang telah difermentasi dimasukkan kedalam tabung $10 \mathrm{~mL}$ steril kemudian di sentrifugasi dengan kecepatan 3000 rpm selama 15 menit, setelah disentrifus, bagian supernatan diambil untuk pengujian aktivitas antibakteri (Noverita, Dinah Fitria, 2009).

\subsection{Uji Aktivitas Antibakteri}

Uji aktivitas antibakteri menggunakan media Nutrien Agar. Bakteri uji yang digunakan yaitu bakteri gram negatif (Escherichia coli) dan bakteri gram positif ( $S$. aureus) dengan metode Kirby-Bauer (metode cakram). Tuang media Nutrian agar ke dalam masing-masing cawan petri steril sebanyak $\pm 20 \mathrm{ml}$ dan didiamkan sampai media menjadi padat selama 15 menit. Bakteri E.coli dan S. aureus yang telah disuspensikan sebelumnya masukkan kedalam cawan petri yang telah berisi media nutrien agar sebanyak $100 \mu 1$ kemudian disebar diatas media tersebut dan di ratakan atau digores menggunakan batang L yang steril hingga biakan bakteri tersebut merata diatas media setelah bakteri merata masukkan kertas cakram yang telah disterilkan terlebih dahulu lalu tetesi kertas cakram tersebut dengan suspensi kapang endofit sebanyak $20 \mu 1$ hinnga kertas cakram tersebut jenuh.

Kontrol positif menggunakan cakram kloramfenikol, sebagai kontrol negatif digunakan kertas cakram steril. Selanjutnya, dilakukan diinkubasi selama 24-48 jam pada suhu $37^{\circ} \mathrm{C}$. Setelah inkubasi, zona bening yang terbentuk dan diukur 
diameternya. Zona bening menunjukkan aktivitas antibakteri dari isolate kapang endofit.

\section{HASIL DAN PEMBAHASAN}

Kapang endofit merupakan mikroorganisme yang hidup di dalam jaringan tumbuhan pada periode tertentu dan membentuk koloni dalam jaringan tumbuhan tetapi tidak merugikan inangnya. Tumbuhan tingkat tinggi dapat mengandung beberapa mikroba endofit yang mampu menghasilkan metabolit sekunder yang sama dengan metabot sekunder yang dihasilkan inangnya (Radji, 2005). Kumaran dkk, (2010) menyatakan bahwa mikroba endofit dapat menghasilkan senyawa berupa enzim, vitamin, antibakteri, antioksidan dan agen farmakologi

Sampel penelitian ini adalah kulit buah nanas (Ananas comosus (L.) Merr) yang merupakan penghasil kapang endofit. Isolasi kapang endofit asal kulit nanas dilakukan menggunakan difusi agar. Sampel tanaman nanas diambil dari lahan perkebunan warga di Tangkit Baru, Kecamatan Sungai Gelam, Kabupaten Muaro Jambi, Provinsi Jambi.

\subsection{Hasil Pemurnian Isolat Kapang Endofit}

Sebanyak 3 isolat kapang endofit yang berhasil diisolasi dari kulit nanas yang diambil dari lahan perkebunan warga di Tangkit Baru yang diberi nama Isolat Ac1, Isolat Ac-II, dan Isolat Ac-III (Gambar 1). Semua isolat tumbuh dengan baik pada media PDA karena media PDA merupakan media selektif untuk pertumbuhan kapang. Media mudah dicerna sehingga memudahkan untuk kapang endofit yang telah berhasil diisolasi lebih mudah untuk tumbuh. Peremajaan kapang endofit bertujuan untuk menjamin kapang endofit agar tidak berada pada fase kematian dipercepat dimana lebih banyak sel-sel yang mati dari pada sel-sel yang hidup (Gandjar, Syamsuridzal \& Oetari, 2006).

Media fermentasi yang digunakan adalah media PDB, karena dalam media ini mengandung sumber karbon dan sumber nitrogen yang diperlukan untuk pertumbuhan kapang endofit. Selain itu juga mengandung garam-garam organik serta beberapa vitamin dan mineral. Proses fermentasi dilakukan selama tujuh hari 
dimana kapang endofit diperkirakan sudah mencapai fase stationer dan menghasilkan metabolit sekunder berupa antibiotik.

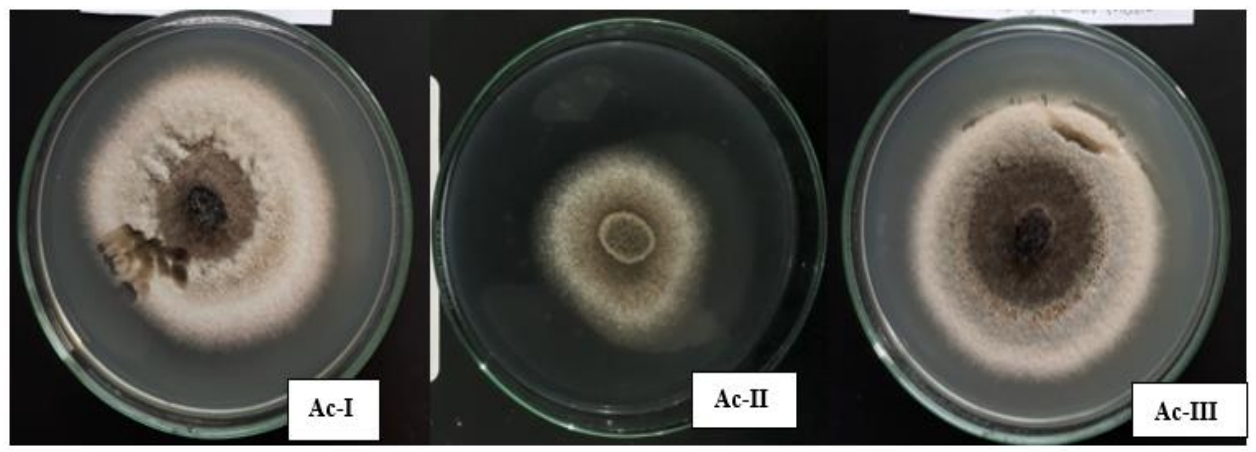

Gambar 1. Hasil isolat murni kapang endofit asal kulit nanas ( Isolat Ac-1, Isolat Ac-II, dan Isolat Ac-III).

\subsection{Hasil Pengamatan Makroskopis}

Isolat yang telah murni kemudian dilakukan pengamatan secara makroskopis. Isolat kapang endofit yang diperoleh diduga mempunyai genus Mucor, dengan karakteristik: koloni kapang endofit ini memiliki hifa bercabang, warna hifa putih kecoklatan hingga kehitam dengan permukaan koloni membentuk cembung, bentuk koloni bundar dengan memiliki tepian menyebar kasar, tidak merata. Warna koloni putih kecoklatan hingga kehitam. Hal ini sesuai dengan hasil penelitian yang diperoleh berdasarkan pengamatan morfologi koloni di atas media padat secara makroskopis (Tabel 1).

\subsection{Hasil Pengamatan Mikroskopis}

Identifikasi kapang endofit dapat dilakukan dengan menggunakan karakterisasi mikroskopis menggunakan larutan LFCB. Penggunaan larutan LFCB pada pengamatan mikroskopis menyebabkan warna biru pada hifa karena larutan LFCB yang digunakan berwarna biru (Gambar 2). 


\subsection{Hasil Uji Aktivitas Antibakteri}

Hasil uji antibakteri isolat kapang endofit terhadap bakteri uji yang dilakukan menggunakan metode Kirby-Bauer (metode cakram) dengan kontrol positif antibiotik kloramfenikol terhadap bakteri Staphylococcus aureus dan bakteri Escherichia coli menunjukkan adanya zona hambat sebesar $28 \mathrm{~mm}$ pada bakteri $S$. aureus sedangkan pada bakteri E. coli memiliki diamater zona hambat sebesar 22 mm, yang terbentuk pada sekeliling cakram. Kedua kontrol positif tersebut memiliki diameter zona hambat yang dikatagorikan sangat kuat. Kloramfenikol merupakan antibiotik spektrum luas yang dapat menghambat pertumbuhan bakteri gram positif dan bakteri gram negatif. Sedangkan pada kontrol negatif tidak ada zona hambat yang terbentuk di sekitar cakram.

Tabel 1. Hasil pengamatan makroskopis kapang endofit

\begin{tabular}{|c|c|c|c|c|}
\hline Isolat & Warna Koloni & Bentuk Koloni & Elevasi & Tepian \\
\hline Ac-1 & $\begin{array}{l}\text { Putih Kecoklatan hingga } \\
\text { kehitaman }\end{array}$ & $\begin{array}{l}\text { Bundar dengan tepian } \\
\text { menyebar }\end{array}$ & Cembung & Bercabang \\
\hline Ac-II & $\begin{array}{l}\text { Putih kecoklatan hingga } \\
\text { kehitamna }\end{array}$ & $\begin{array}{l}\text { Bundar dengan tepian } \\
\text { menyebar }\end{array}$ & Cembung & Bercabang \\
\hline $\begin{array}{l}\text { Ac- } \\
\text { III }\end{array}$ & $\begin{array}{l}\text { Putih kecoklatan hingga } \\
\text { kehitaman }\end{array}$ & $\begin{array}{l}\text { Bundar dengan tepian } \\
\text { menyebar }\end{array}$ & Cembung & Bercabang \\
\hline
\end{tabular}

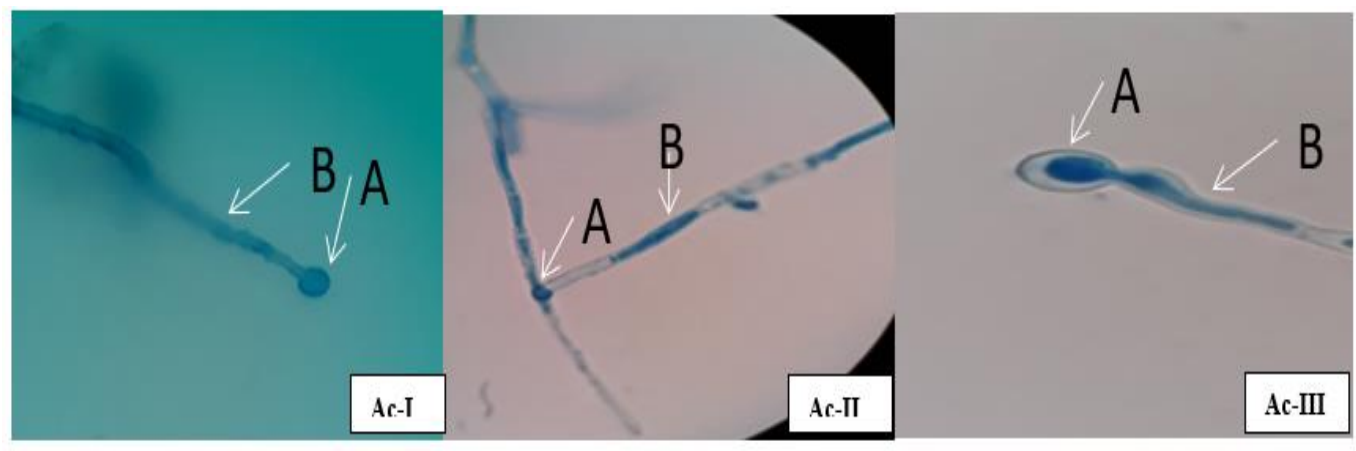

Gambar 2. Hasil pengamatan mikroskopis. Ac = Ananas comosus, $\mathrm{A}=$ Sporangiospora, $\mathrm{B}=$ Hifa 

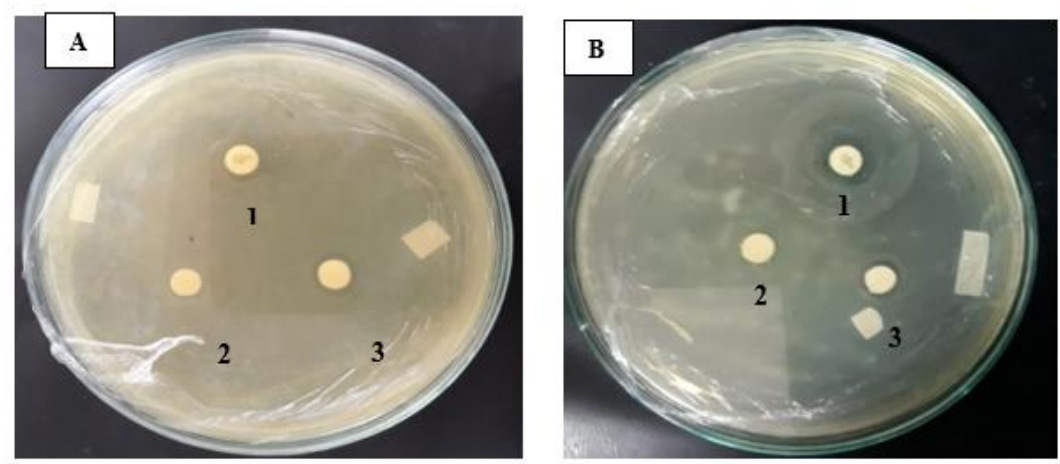

Gambar 3. Hasil uji aktivitas antibakteri isolat kapang endofit.terhadap bakteri A.S. Aureus; B. E. coli. 1 = Cakram kloramfenikol (kontrol +); $2=$ Kontrol negatif (cakram steril); 3 = Isolat Isolat Ac-III

Menurut penelitian yang dilakukan Fitriana, et al (2016) bahwa kapang endofit mempunyai aktivitas antibakteri, sama halnya pengujian aktivitas antibakteri yang di lakukan menggunakan metode Kirby-Bauer yang lebih sering dikenal dengan sebutan metode cakram. Hasil dari penelitian yang diperoleh dari isolat Ac-III dapat menghambat pertumbuhan bakteri Staphylococcus aureus dengan diameter hambat sebesar 7,65 mm dan pada bakteri Eschericia coli sebesar 6,9 mm. Hal ini ditandai dengan adanya zona bening yang terdapat di sekitar paper disk. Sama halnya pada penelitian sebelumnya yang telah dilakukan menunjukkan hasil pada daun nanas dan daging nanas mampu menghambat bakteri Staphylococcus aureus dan Eschericia coli hal ini ditandai dengan adanya zona hambat yang terbentuk disekitar paper disk. Hal ini diduga bahwa isolat kapang endofit yang terdapat pada kulit nanas mampu menghasilkan senyawa metabolit sekunder yang sama dengan yang dihasilkan oleh tumbuhan inangnya (Rahmat et al., 2015).

Perbedaan aktivitas dari senyawa antibakteri yang terdapat pada isolat kapang endofit terhadap bakteri uji $S$. aureus dan bakteri E. coli disebabkan karena perbedaan dinding selnya, E.coli yang merupakan bakteri gram negatif yang memiliki struktur dinding selnya yang tersusun atas tiga lapis yaitu lipoprotein, fosfolipit dan polimer atau yang biasa disebut lipopolisakarida, sedangkan bakteri S. aureus adalah bakteri Gram positif yang memiliki dinding relative lebih sederhana karena berupa sel berlapis tunggal (Polapa, 2015). Kemampuan daya hambat bakteri uji ditandai dengan terbentuknya zona bening disekitar cakram uji, 
jika diameter hambatnya lebih dari $20 \mathrm{~mm}$ dikategorikan sangat kuat, 10-20 dikategorikan kuat, 5-10 mm dikategorikan sedang dan kurang dari $5 \mathrm{~mm}$ dikategorikan lemah (Rante, Herlina, Taebe, 2013). Hasil penelitian ini melaporkan bahwa aktivitas antibakteri isolat kapang endofit Ac-III dikategorikan sedang karena mamiliki daya hambat 7,65 pada bakteri uji S. aureus dan 6,9 mm diameter zona hambat pada bakteri E. coli.

\section{KESIMPULAN DAN SARAN}

\subsection{Kesimpulan}

Isolat kapang endofit asal kulit buah nanas yang masih muda (hijau) diduga berasal dari genus Mucor dan memiliki aktivitas sebagai antibakteri baik pada bakteri gram positif maupun gram negatif.

\subsection{Saran}

Perlu dilakukan identifikasi molekuler untuk mengidentifikasi jenis kapang endofit pada kulit buah nanas.

\section{DAFTAR PUSTAKA}

Crozier, J., Thomas, S. E., Aime, M. C., Evans, H. C., \& Holmes, K. A. (2006). Molecular characterization of fungal endophytic morphospecies isolated from stems and pods of Theobroma cacao. Plant Pathology. https://doi.org/10.1111/j.1365-3059.2006.01446.x

Eshamah, H., Han, I., Naas, H., Rieck, J., \& Dawson, P. (2013). Bactericidal Effects of Natural Tenderizing Enzymes on Escherichia Coli and Listeria monocytogenes. Journal of Food Research. https://doi.org/10.5539/jfr.v2n1p8

Faeth, S. H., \& Fagan, W. F. (2002). Fungal endophytes: Common host plant symbionts but uncommon mutualists. Integrative and Comparative Biology. https://doi.org/10.1093/icb/42.2.360

Febri Walpajri, Rodesia M. Roza, F. (2014). Eksplorasi dan uji daya hambat bakteri endofit dari tanaman benalu sawo (. JOM FMIPA, 1(2), 1-10.

Fitriana, Maryam, S., Naid, T., \& Maryana. (2016). Penelusuran Fungi Endofit Sebagai Penghasil Senyawa Antibiotika Dari Daun Nanas (Ananas comosus (L) Meer). J. As-Syifaa. 
Fitriarni, D., \& Kasiamdari, R. S. (2018). Isolation and Identification of Endophytic Fungi from Leave and Stem of Calopogonium mucunoides. Journal of Tropical Biodiversity and Biotechnology, 3(1), 30. https://doi.org/10.22146/jtbb.32477

Husniah, I., \& Gunata, A. F. (2020). Ekstrak Kulit Nanas sebagai Antibakteri. Jurnal Penelitian Perawat Profesional, 2(1), 85-90. https://doi.org/10.37287/jppp.v2i1.51

Kumaran, R. S., Kim, H. J., \& Hur, B. K. (2010). Taxol promising fungal endophyte, Pestalotiopsis species isolated from Taxus cuspidata. Journal of Bioscience and Bioengineering. https://doi.org/10.1016/j.jbiosc.2010.06.007

Mousa, W. K., \& Raizada, M. N. (2013). The Diversity of Anti-Microbial Secondary Metabolites Produced by Fungal Endophytes: An Interdisciplinary Perspective. Frontiers in Microbiology. https://doi.org/10.3389/fmicb.2013.00065

Noverita, Dinah Fitria, E. S. F. (2009). Isolasi Dan Uji Aktivitas Antibakteri Jamur Endofit Dari Daun Dan Rimpang. Farmasi Indonesia.

Nurhidayah, N., Masriany, M., \& Masri, M. (2013). Isolasi dan Pengukuran Aktivitas Enzim Bromelin dari Ekstrak Kasar Batang Nanas (Ananas comosus) Berdasarkan Variasi pH. Biogenesis: Jurnal Ilmiah Biologi, 1(2), 116-122. https://doi.org/10.24252/bio.v1i2.457

Polapa, F. S. (2015). Antibakteri dari Ekstrak Kasar Bakteri Asosiasi Karang Batu yang terinfeksi Penyakit Brown Band (Brb) terhadap Bakteri Patogen Staphylococcus Aureus dan, Skripsi FIKP.

Radji, M. (2005). Peranan Bioteknologi Dan Mikroba Endofit Dalam Pengembangan Obat Herbal. Majalah Ilmu Kefarmasian. https://doi.org/10.7454/psr.v2i3.3388

Rahmat, D., Ratih L., D., Nurhidayati, L., \& Ayu Bathini, M. (2015). Peningkatan Aktivitas Antimikroba Ekstrak Nanas (Ananas comosus (L.). Merr) dengan Pembentukan Nanopartikel. Jurnal Sains Dan Kesehatan, 1(5), 236-244. https://doi.org/10.25026/jsk.v1i5.45

Rante, Herlina, Taebe, B. dan I. S. (2013). Isolasi Fungi Endofit Penghasil Senyawa Antimikroba Dari Daun Cabai Katokkon (Capsicum annuum L var. chinensis) Dan Profil Klt Bioautografi. Majalah Farmasi Dan Farmakologi.

Roze, L. V., Chanda, A., \& Linz, J. E. (2011). Compartmentalization and molecular traffic in secondary metabolism: A new understanding of established 
No.

cellular processes. Fungal Genetics and Biology. https://doi.org/10.1016/j.fgb.2010.05.006

Van Antwerpen, T., Rutherford, R., \& Vogel, J. (2002). Assessment of sugarcane endophytic bacteria and rhizospheric Burkholderia species as antifungal agents. Proc Annu Congr S Afr Sugar Technol Assoc. 